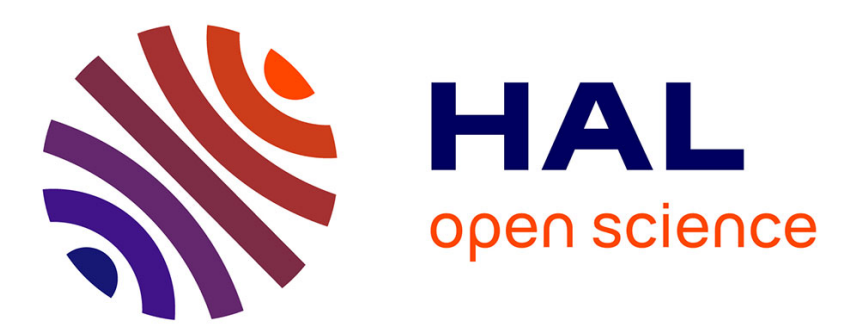

\title{
Cyclic peptides bearing a side-chain tail: A tool to model the structure and reactivity of protein zinc sites.
}

Olivier Sénèque, Emilie Bourlès, Vincent Lebrun, Estelle Bonnet, Pascal Dumy, Jean-Marc Latour

\section{- To cite this version:}

Olivier Sénèque, Emilie Bourlès, Vincent Lebrun, Estelle Bonnet, Pascal Dumy, et al.. Cyclic peptides bearing a side-chain tail: A tool to model the structure and reactivity of protein zinc sites.. Angewandte Chemie International Edition, 2008, 47 (36), pp.6888-6891. 10.1002/anie.200800677 . hal-00373744

\author{
HAL Id: hal-00373744 \\ https://hal.science/hal-00373744
}

Submitted on 7 Apr 2009

HAL is a multi-disciplinary open access archive for the deposit and dissemination of scientific research documents, whether they are published or not. The documents may come from teaching and research institutions in France or abroad, or from public or private research centers.
L'archive ouverte pluridisciplinaire HAL, est destinée au dépôt et à la diffusion de documents scientifiques de niveau recherche, publiés ou non, émanant des établissements d'enseignement et de recherche français ou étrangers, des laboratoires publics ou privés. 


\title{
Cyclic Peptides Bearing a Side-Chain Tail: A Tool to Model the Structure and Reactivity of Protein Zinc Sites
}

\author{
Olivier Sénèque, ${ }^{a} *$ Emilie Bourlès, ${ }^{a}$ Vincent Lebrun, ${ }^{b}$ Estelle Bonnet,${ }^{a}$ Pascal Dumy, ${ }^{c}$ Jean- \\ Marc Latour *
}

a) Laboratoire de Chimie et Biologie des Métaux, CNRS UMR 5249, 17, rue des Martyrs, 38054

Grenoble (France), Fax: (+33) 438783462.

b) CEA, iRTSV, LCBM, 17, rue des Martyrs, 38054 Grenoble (France).

\begin{abstract}
c) Département de Chimie Moléculaire, UMR CNRS-UJF 5250, 301 Rue de la Chimie, Université Joseph Fourier, BP 5338041 Grenoble Cedex 9 (France)
\end{abstract}

E-mail: olivier.seneque@cea.fr; jean-marc.latour@cea.fr

A recent bioinformatic study has evaluated to about 1000 (or ca $3 \%$ of the total protein number) the number of human proteins possessing a tetracysteinate zinc site. ${ }^{[1]}$ These sites were initially supposed to have a structural role since they were associated to zinc finger proteins ${ }^{[2]}$ where they fold the protein chain in a conformation suitable to its binding to DNA. They were later found in several proteins and enzymes involved in demethylation processes such as the DNA repair protein $\mathrm{Ada}^{[3]}$ and various transferases. ${ }^{[4]}$ More recently, such sites were discovered in the heat shock protein Hsp33, ${ }^{[5]}$ and the disulfide reductase $\operatorname{Tr} \times 2^{[6]}$ where their interaction with reactive oxygen species (ROS) contributes to the oxidative stress response. This is of special interest since tetracysteinate zinc sites, especially in zinc finger proteins, have been considered to be likely targets of ROS. Free cysteines are commonly involved in peroxide sensing and response $\mathrm{e}^{[7]}$ and their reactivity has been thoroughly studied over the past twenty years. A reasonable reactivity picture has emerged that points to the importance of hydrogen-bonding to increase the nucleophilic character of the cysteine sulfur. No such rationale is available for metal-bound cysteinates.

In order to get a better understanding of the reactivity of tetracysteinate zinc sites with ROS, we are developing a biomimetic approach based on de novo peptide synthesis. This approach is particularly suited to mimicking these sites and the potentially important hydrogen-bonding interactions, which is not possible with metalloorganic complexes in organic solvents. The validity of this approach has been demonstrated by Berg et al. in their modeling studies of zinc finger proteins with a mixture of cysteinate and histidine ligands ${ }^{[8]}$ and further highlighted more recently by Gibney et $a l .{ }^{[9]}$ Both groups used linear 16- to 26-mer peptides incorporating two $\mathrm{CX}_{\mathrm{n}} \mathrm{C}(\mathrm{n}=2-4)$ zinc binding motif. Regan et al. ${ }^{[10]}$ relied on self-assembling peptides to constitute a four-helix bundle orienting the cysteinates in the proper way to bind zinc. Nevertheless, this approach is generally weakened by the difficulty to obtain detailed structural characterization of metallopeptides. In addition, these two designs cannot reproduce the tetracysteinate arrangements that belong to $\beta$-hairpins such as that of Hsp33. ${ }^{[5]}$ This prompted us to develop a totally new design based on introducing one $\mathrm{CX}_{\mathrm{n}} \mathrm{C}$ motif into 
a cyclic peptide and another one into a linear chain connected to the cycle via a glutamate or a lysine. In this communication, we show that this peptide design, with limited size and flexibility, allows to reproduce almost perfectly both the structure and the reactivity of the tetracysteinate zinc site of the protein Hsp33.

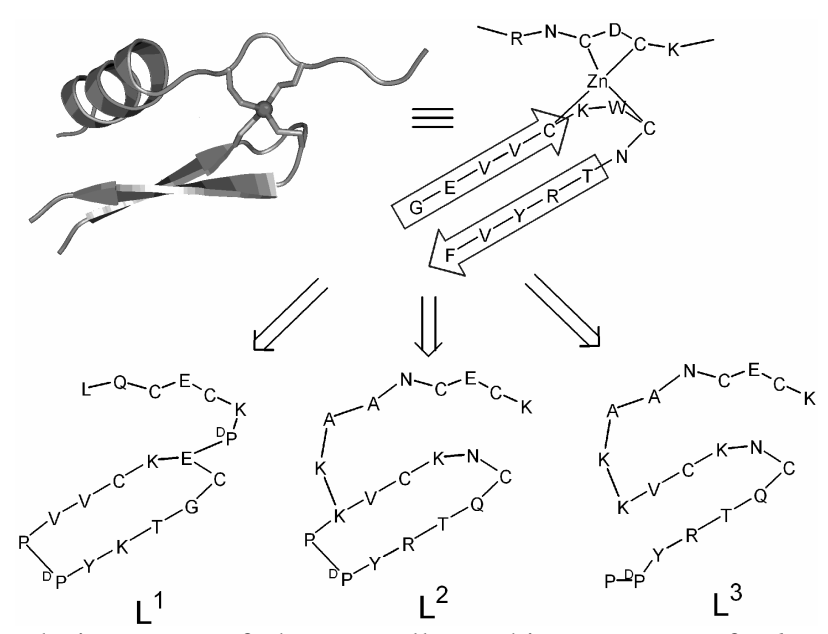

Figure 1. Model peptides design. Part of the crystallographic structure of Thermotoga maritima Hsp33 ${ }^{[5]}$ showing the $\mathrm{Zn}(\mathrm{Cys})_{4}$ site (upper left), its schematic representation (upper right) and the model peptides $\mathbf{L}^{\mathbf{1}}, \mathbf{L}^{\mathbf{2}}$ and $\mathbf{L}^{3}$ (bottom). Some of the amino-acids were changed in the models to prevent overlapping in the NMR spectra.

Figure 1 illustrates the tetracysteinate zinc site of $\mathrm{Hsp33}$ that consists of a CXXC motif $\left.\mathrm{C}_{263} \mathrm{KWC}_{266}\right)$ located in a $\beta$-hairpin loop and a $\mathrm{CXC}$ motif $\left(\mathrm{C}_{231} \mathrm{DC}_{233}\right)$. To reproduce the topology of this site, we designed a cyclic peptide to mimic the $\beta$-hairpin loop ${ }^{[11]}$ and a linear tail was grafted on one of the side-chains of the loop to introduce the CXC motif. The D-Pro-L-Pro dipeptide template was used to preorganize the ten residues constituting the $\beta$-hairpin loop. ${ }^{[11]}$ The linear tail was grafted on a Glu residue of the cycle via its $\mathrm{N}$-end (peptide $\mathbf{L}^{1}$ ) or on a Lys residue via its C-end (peptide $\mathbf{L}^{2}$ ). The linear precursor of $\mathbf{L}^{\mathbf{1}}$ was assembled on Sieber amide resin using Fmoc chemistry. Fmoc-GluOAll was used to create the branching point between the two parts of the peptide (scheme 1). After selective removal of the allyl group with $\mathrm{Pd}^{0}$, cleavage from the resin with $1 \%$ trifluoroacetic acid (TFA) in $\mathrm{CH}_{2} \mathrm{Cl}_{2}$ yielded a linear peptide amidated at the $\mathrm{C}$-terminal leucine and still bearing the sidechain protecting groups. Cyclization between the only two unprotected functions (main chain Glu$\mathrm{COOH}$ and $\mathrm{Cys}-\mathrm{NH}_{2}$ ) in $\mathrm{CH}_{2} \mathrm{Cl}_{2}$ followed by removal of the side-chain protecting groups by TFA/triisopropylsilane (TIS)/ $\mathrm{H}_{2} \mathrm{O} /$ dithiotreitol (DTT) and HPLC purification yielded $\mathbf{L}^{1}$. The peptide $\mathbf{L}^{2}$ was synthesized in a similar way on 2-chlorotrityl chloride resin using Alloc-Lys(Fmoc)-OH to introduce the branching point. To assess the value of the design described above, $\mathbf{L}^{3}$, the linear analogue of $\mathbf{L}^{2}$, was synthesized by suppressing the cyclization step. All peptides were identified by ESI/MS and ${ }^{1} \mathrm{H}$ NMR. 


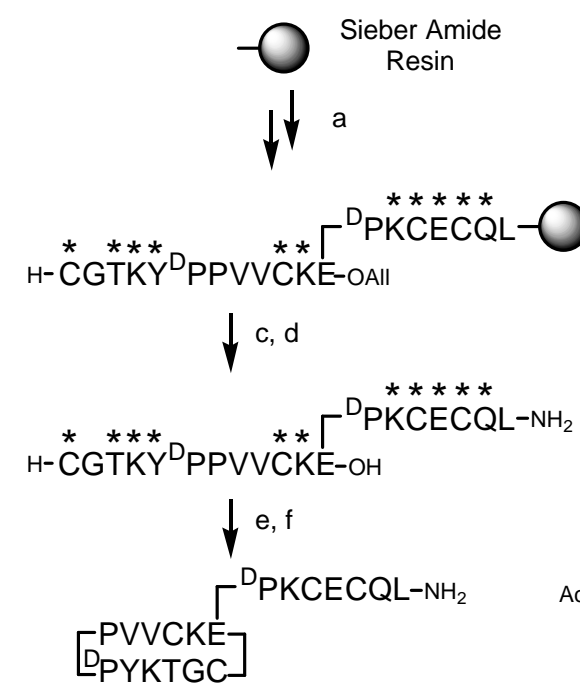

$\left(L^{1}\right)$

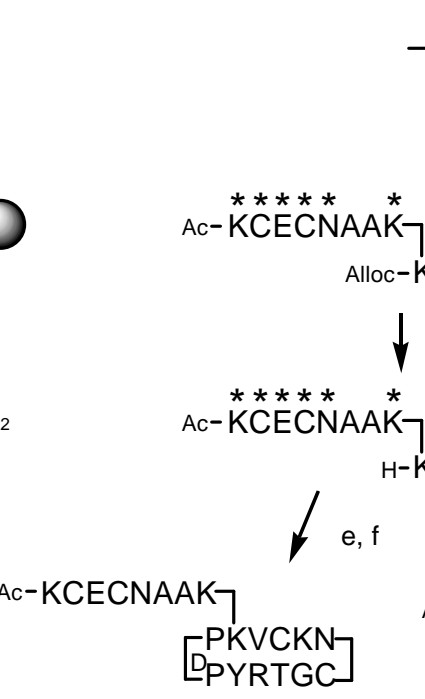

$\left(L^{2}\right)$ $\mathrm{AK}_{7}$

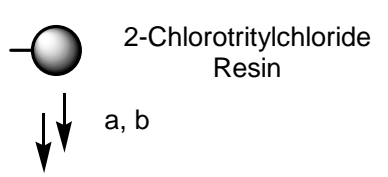
$-K V C K N C{ }^{*} T^{*} R{ }^{\mathrm{D}} \mathrm{PP}-$ c, d -KVCKNNCQRTRY ${ }^{\star *} \mathrm{PP}-\mathrm{OH}$

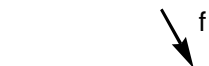
Ac-KCECNAAK H-KVCKNCQTRYDPP-OH

$\left(\mathrm{L}^{3}\right)$

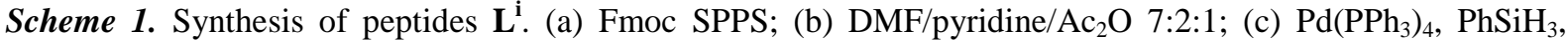
$\mathrm{CH}_{2} \mathrm{Cl}_{2}$; (d) $\mathrm{CH}_{2} \mathrm{Cl}_{2} / \mathrm{TFA}$ 99:1; (e) $0.25 \mathrm{mM}$, PyBOP, DIEA, $\mathrm{CH}_{2} \mathrm{Cl}_{2}$; (f) TFA/TIS/H $\mathrm{H}_{2} \mathrm{O} / \mathrm{DTT}$. * denotes sidechain protecting groups.

Metal binding was investigated by UV/Vis, $\mathrm{CD}$ and fluorescence titrations at $\mathrm{pH}$ 7.0. Titrations with $\mathrm{Co}^{2+}$ show the formation of a unique 1:1 complex $\mathbf{C o} \cdot \mathbf{L}^{\mathbf{i}}$ for each of the three peptides. The LMCT and d-d transitions of these complexes are consistent with a $\mathrm{Co}^{2+}$ ion coordinated by four cysteinates in a tetrahedral geometry (Table 1). ${ }^{[12]}$ The $\mathrm{d}$-d transition patterns of the three $\mathbf{C o} \cdot \mathbf{L}^{\mathbf{i}}$ complexes differ quite significantly but the spectra of $\mathbf{C o} \cdot \mathbf{L}^{2}$ and Co.Hsp33 ${ }^{[13]}$ are strikingly similar (Figure S1). With $\mathrm{Zn}^{2+}$, the three peptides exhibit distinct behaviors. $\mathbf{L}^{2}$ forms only a 1:1 complex $\left(\mathbf{Z n} \cdot \mathbf{L}^{2}\right)$ while $\mathbf{L}^{3}$ forms also a complex of undefined stoichiometry in excess of zinc, and $\mathbf{L}^{1}$ forms also a 1:2 $\mathbf{Z n} \cdot\left(\mathbf{L}^{\mathbf{1}}\right)_{2}$ complex, detected during CD titration in conditions of excess peptide. The LMCT band of the $\mathbf{Z n} \cdot \mathbf{L}^{\mathbf{i}}$ complexes around $210 \mathrm{~nm}$ indicates that the metal is coordinated by the four thiolates. ${ }^{[14]}$ The apparent binding constants are $10^{9.9(2)}$ and $10^{8.6(2)}$ at $\mathrm{pH} 7.0$ for $\mathbf{C o} \cdot \mathbf{L}^{2}$ and $\mathbf{C o} \cdot \mathbf{L}^{\mathbf{3}}$, respectively, and are $10^{16.3(2)}$ and $10^{15.2(2)}$ for $\mathbf{Z n} \cdot \mathbf{L}^{2}$ and $\mathbf{Z n} \cdot \mathbf{L}^{\mathbf{3}}$, respectively, at $\mathrm{pH}$ 7.5. Thus, the complexes formed by the cyclic peptide $\mathbf{L}^{2}$ are more stable than those of its linear analogue $\mathbf{L}^{3}$ by approximately one order of magnitude. The value measured for $\mathbf{Z n} \cdot \mathbf{L}^{2}$ is very similar to that reported for $\mathrm{Zn} \cdot \mathrm{Hsp} 33\left(10^{16.6}\right)$ at $\mathrm{pH} 7.5 .^{[15]}$

Table 1. UV-Vis characterizations of $\mathrm{Co}^{2+}$ and $\mathrm{Zn}^{2+}$ complexes of peptides $\mathbf{L}^{\mathrm{i}}$ at $\mathrm{pH}$ 7.0.

\begin{tabular}{ll}
\hline Complex & $\lambda(\Delta \varepsilon) / \mathrm{nm}\left(\mathrm{M}^{-1} \mathrm{~cm}^{-1}\right)$ \\
\hline $\mathbf{C o} \cdot \mathbf{L}^{1}$ & $302(6460), 360(3980), 645(630), 685(835), 726(930)$ \\
$\mathbf{C o} \cdot \mathbf{L}^{2}$ & $300(4270), 347(3200), 635(369), 686(769), 722(697)$ \\
$\mathbf{C o} \cdot \mathbf{L}^{3}$ & $310(4080), 356(2860), 617(408), 680(570), 741(407)$ \\
$\mathbf{Z n} \cdot \mathbf{L}^{\mathbf{1}}$ & $213(19600)$ \\
$\mathbf{Z n} \cdot \mathbf{L}^{\mathbf{2}}$ & $204(23700)$ \\
$\mathbf{Z n} \cdot \mathbf{L}^{3}$ & $211(20600)$ \\
\hline
\end{tabular}

The structures of the zinc complexes were investigated by ${ }^{1} \mathrm{H}$ NMR spectrometry. The ${ }^{1} \mathrm{H}$ NMR spectra of complexes $\mathbf{Z n} \cdot \mathbf{L}^{\mathbf{i}}$ are depicted in figure 2. Whereas $\mathbf{Z n} \cdot \mathbf{L}^{\mathbf{1}}$ and $\mathbf{Z n} \cdot \mathbf{L}^{2}$ display well 
resolved spectra, $\mathbf{Z n} \cdot \mathbf{L}^{3}$ displays broad peaks characteristic of conformational motion. Thus only the cyclic peptide-based models $\mathbf{Z n} \cdot \mathbf{L}^{1}$ and $\mathbf{Z n} \cdot \mathbf{L}^{2}$ are suitable for a detailed structure determination. Their $\mathrm{NH}$ resonances are spread over the 7-9.5 ppm range, most of the ${ }^{3} J_{\mathrm{NH}, \mathrm{H} \alpha}$ values are out of the $6-8 \mathrm{~Hz}$ range and a large number of NOE cross peaks are observed between the cycle and the tail (Supplementary information). This clearly indicates that $\mathbf{Z n} \cdot \mathbf{L}^{1}$ and $\mathbf{Z n} \cdot \mathbf{L}^{\mathbf{2}}$ adopt a well defined conformation. The numerous cross-strand NOEs show that the cycle folds in a regular $\beta$-hairpin. ${ }^{[16]}$ The NOE pattern of the four cysteines and the ${ }^{3} J_{\mathrm{H} \alpha \mathrm{H} \beta}$ values show that the positions of the cysteine side-chains are well defined. ${ }^{[17]}$ The structure was calculated using the program XPLOR $3.851^{[18]}$ with $247 \mathrm{H}-\mathrm{H}$ distances constraints (81 intra-residue, 78 sequential and 88 medium-range) extracted from the NOESY spectra (200 ms) and $12 \phi$ and $3 \chi_{1}$ dihedral constraints for $\mathbf{Z n} \cdot \mathbf{L}^{\mathbf{1}}$ and with $255 \mathrm{H}-\mathrm{H}$ distances constraints (91 intra-residue, 66 sequential and 98 medium-range) and $12 \phi$ and $4 \chi_{1}$ dihedral constraints for $\mathbf{Z n} \cdot \mathbf{L}^{2}$. The superposition of the lowest energy structures with the zinc site of Thermotoga maritima Hsp33 are depicted in figure 3. Both model peptides perfectly reproduce the hairpin loop (the backbone root mean square deviation (r.m.s.d.) is $0.57 \AA$ and $0.40 \AA$ for $\mathbf{Z n} \cdot \mathbf{L}^{1}$ and $\mathbf{Z n} \cdot \mathbf{L}^{\mathbf{2}}$ respectively). The linear tail of $\mathbf{Z n} \cdot \mathbf{L}^{1}$ is slightly tilted from the corresponding sequence in $\mathrm{Zn} \cdot \mathrm{Hsp} 33$ whereas a perfect match is noted for $\mathbf{Z n} \cdot \mathbf{L}^{2}$, with exactly the same relative orientation for the four cysteines side-chains. All of the seven hydrogen bonds involving the cysteine sulfurs in the $\mathrm{X}$ Ray structure of Hsp33 are reproduced in the model compound $\mathbf{Z n} \cdot \mathbf{L}^{2}$ whereas $\mathbf{Z n} \cdot \mathbf{L}^{1}$ lacks one.

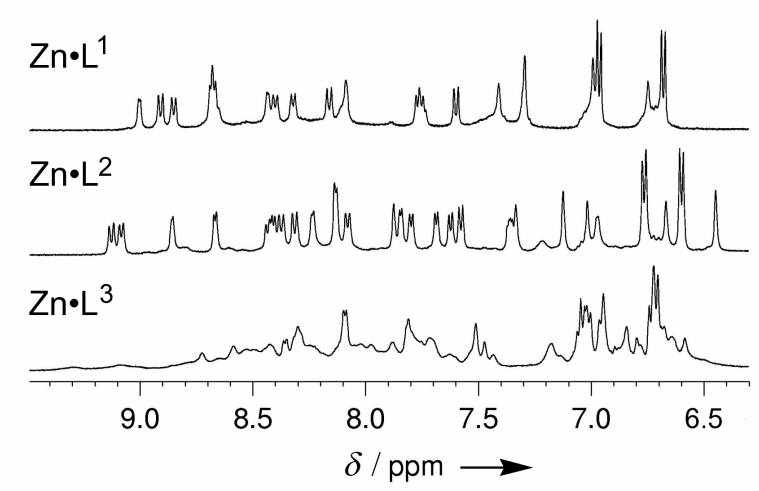

Figure 2. $\mathrm{NH}$ and aromatic region of ${ }^{1} \mathrm{H}$ NMR spectra (500 MHz, $298 \mathrm{~K}, \mathrm{H}_{2} \mathrm{O} / \mathrm{D}_{2} \mathrm{O}$ 9:1, pH 6.2) of complexes peptides $\mathbf{Z n} \cdot \mathbf{L}^{\mathbf{i}}$ prepared by adding 1.0 equivalent of $\mathrm{Zn}^{2+}$ to the peptide $\mathbf{L}^{\mathbf{i}}$. 

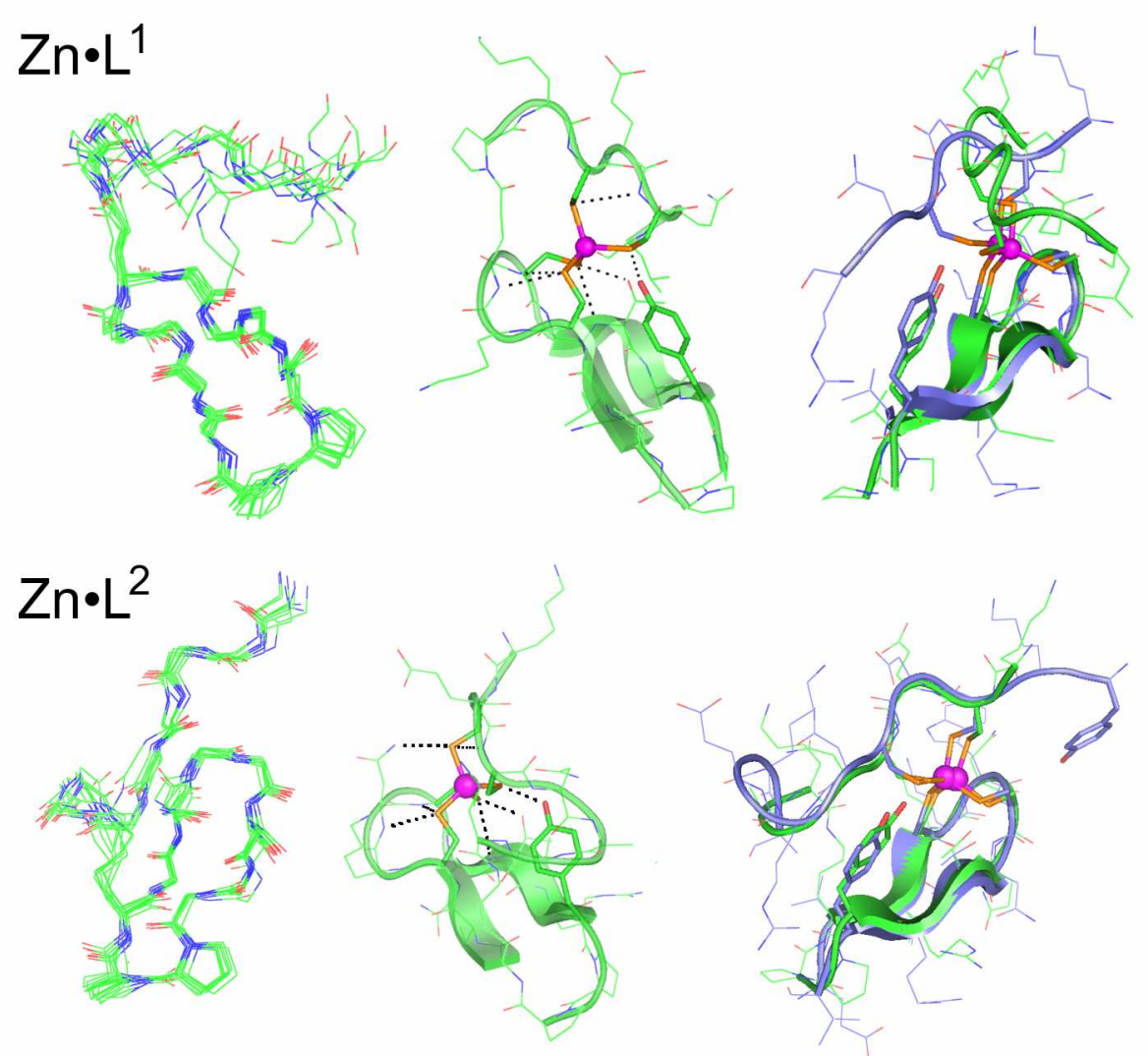

Figure 3. NMR Solution structures of $\mathbf{Z n} \cdot \mathbf{L}^{\mathbf{1}}$ and $\mathbf{Z n} \cdot \mathbf{L}^{\mathbf{2}}$. Left: Superposition of the 10 lowest energy NMR structures calculated using XPLOR. Middle: Lowest energy structure showing the hydrogen bond network (black). Right: Superposition of the lowest energy structure of $\mathbf{Z n} \cdot \mathbf{L}^{\mathbf{i}}$ (green) with the zinc site of Thermotoga maritima Hsp33 (pdb 1VQ0, blue).

In a preliminary reactivity study with ROS, we investigated the oxidation of the three $\mathbf{Z n} \cdot \mathbf{L}^{\mathbf{i}}$ complexes with $\mathrm{H}_{2} \mathrm{O}_{2}$. The reaction of $\mathbf{Z n} \cdot \mathbf{L}^{\mathbf{i}}$ with excess $\mathrm{H}_{2} \mathrm{O}_{2}$ was followed by ESI/MS, UV/Vis and fluorescence. $\mathbf{Z n} \cdot \mathbf{L}^{\mathrm{i}}, \mathbf{L}_{\text {SS }}^{\mathrm{i}}$ and $\mathbf{L}_{2 \text { SSS }}^{\mathrm{i}}$ (the peptides presenting one and two disulfides, respectively) were observed by ESI/MS, the latter being the only species at the end of the reaction. Tyrosine fluorescence was recorded as a function of time (figure 4). The decrease of the fluorescence correlates with the decrease of the LMCT band at ca $210 \mathrm{~nm}$ monitored by UV/Vis. Fluorescence kinetic measurements allowed us to monitor the destruction of the $\mathrm{Zn}(\mathrm{Cys})_{4}$ centre and the formation of disulfides which are efficient quenchers of tyrosine fluorescence. ${ }^{[19]}$ The kinetic traces were perfectly fitted with a single exponential. The apparent pseudo-first order constant $\mathrm{k}_{\mathrm{obs}}$ is proportional to $\left[\mathrm{H}_{2} \mathrm{O}_{2}\right]$. Therefore, the oxidation follows a second order kinetic law $\mathrm{r}=\mathrm{k} \times\left[\mathbf{Z n} \cdot \mathbf{L}^{\mathrm{i}}\right] \times\left[\mathrm{H}_{2} \mathrm{O}_{2}\right]$ showing that the rate determining step corresponds to the bimolecular reaction of $\mathbf{Z n} \cdot \mathbf{L}^{\mathbf{i}}$ with $\mathrm{H}_{2} \mathrm{O}_{2}$, with a highly ordered transition state as shown by the large negative value of $\Delta \mathrm{S}^{\ddagger}$ derived from Eyring plots (table 2). Interestingly, the kinetic constants at $303 \mathrm{~K}$ and $316 \mathrm{~K}$ for the best structural model $\mathbf{Z n} \cdot \mathbf{L}^{2}$ are in excellent agreement with those deduced from the data reported for Zn.Hsp33. ${ }^{[20]}$ Moreover, it seems that the oxidation kinetics parallel the structural ordering of the zinc site. With one missing hydrogen bond, $\mathbf{Z n} \cdot \mathbf{L}^{1}$ is oxidized more rapidly than $\mathbf{Z n} \cdot \mathbf{L}^{2}$ and consistently, the fastest oxidation is observed for $\mathbf{Z n} \cdot \mathbf{L}^{\mathbf{3}}$, which has no defined conformation and thus no defined hydrogen bond network. 
Table 2. Kinetic parameters for the oxidation of $\mathbf{Z n} \cdot \mathbf{L}^{\mathbf{i}}$ by $\mathrm{H}_{2} \mathrm{O}_{2}$.

\begin{tabular}{lllll}
\hline & $\mathbf{Z n} \cdot \mathbf{L}^{1}$ & $\mathbf{Z n} \cdot \mathbf{L}^{2}$ & $\mathbf{Z n} \cdot \mathbf{L}^{\mathbf{3}}$ & $\mathbf{Z n} \cdot \mathbf{H s p 3 3}{ }^{[a]}$ \\
\hline $\mathrm{k}_{303 \mathrm{~K}} / \mathrm{M}^{-1} \mathrm{~s}^{-1}$ & $0.20(1)$ & $0.13(1)$ & $0.57(2)$ & $0.12(1)$ \\
$\mathrm{k}_{316 \mathrm{~K}} / \mathrm{M}^{-1} \mathrm{~s}^{-1}$ & $0.45(2)$ & $0.28(1)$ & $1.2(1)$ & $0.31(3)$ \\
$\Delta \mathrm{H}^{\neq} / \mathrm{kJ} \mathrm{mol}^{-1}$ & $47.8(5)$ & $43.1(5)$ & $45.1(5)$ & - \\
$\Delta \mathrm{S}^{\neq} / \mathrm{J} \mathrm{mol}^{-1} \mathrm{~K}^{-1}$ & $-101(2)$ & $-120(2)$ & $-101(2)$ & - \\
\hline
\end{tabular}

[a] Kinetic constants were obtained from ref. ${ }^{[20]}$ by converting half-life reaction time of $\mathbf{Z n} \cdot \mathbf{H s p 3 3}$ with $2 \mathrm{mM} \mathrm{H}_{2} \mathrm{O}_{2}$ using the formula $\mathrm{k}=\left(\ln 2 / t_{1 / 2}\right) /\left[\mathrm{H}_{2} \mathrm{O}_{2}\right]$.

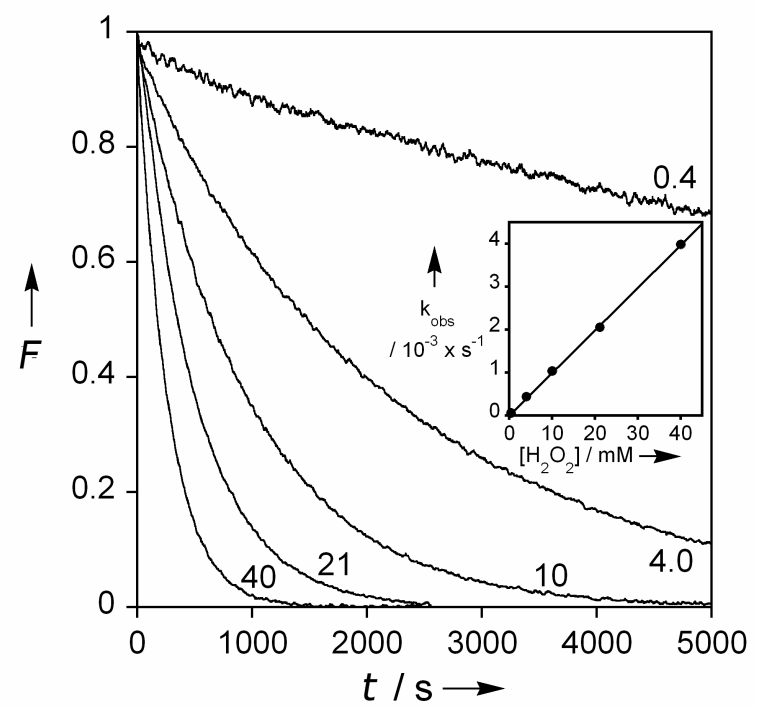

Figure 4. Normalized tyrosine fluorescence changes $\left(\lambda_{\mathrm{ex}}=280 \mathrm{~nm}, \lambda_{\mathrm{em}}=307 \mathrm{~nm}\right)$ observed during reaction of $\mathbf{Z n} \cdot \mathbf{L}^{2}(20 \mu \mathrm{M})$ with excess $\mathrm{H}_{2} \mathrm{O}_{2}$ at $298 \mathrm{~K}, \mathrm{pH}$ 7.0. The numbers denotes the $\mathrm{H}_{2} \mathrm{O}_{2}$ concentrations in mM. The inset shows the $\mathrm{k}_{\mathrm{obs}}$ obtained by fitting each kinetic trace with a single exponential as a function of $\left[\mathrm{H}_{2} \mathrm{O}_{2}\right]$.

In summary, we have devised a new design based on branched cyclic peptides to mimic the tetracysteinate-zinc sites belonging to a $\beta$-hairpin such as the $\mathrm{Zn}(\mathrm{Cys})_{4}$ site of $\mathrm{Hsp} 33$. This is achieved with short peptides $(\approx 20$ amino-acids) which are easy to synthesize. Moreover their limited size allows a rapid NMR structural characterization, what can be scarcely achieved with linear peptides or multi-helix bundles. The differences between $\mathbf{L}^{2}$ and $\mathbf{L}^{3}$ highlight the interest of this design over the use of linear peptides for the modelling of structural properties and reactivity. The comparison between $\mathbf{L}^{1}$ and $\mathbf{L}^{2}$ shows that small changes in the structure and in the H-bonding pattern of theses complexes can influence their reactivity. The oxidation of these $\mathrm{Zn}(\mathrm{Cys})_{4}$ sites in condition of severe $\mathrm{H}_{2} \mathrm{O}_{2}$ stress $(100 \mu \mathrm{M}-5 \mathrm{mM})$ is very slow with half-life reaction times of several minutes, suggesting that $\mathrm{H}_{2} \mathrm{O}_{2}$ might not be the ROS actually responsible for the oxidation in vivo. We are further exploring the reactivity of these promising models towards $\mathrm{H}_{2} \mathrm{O}_{2}$ and other ROS.

Acknowledgments: The authors thank Mrs C. Lebrun for access to ESI-MS spectrometer and the Agence Nationale de la Recherche (ANR-06-JCJC-0018) for financial support. 
Keywords: bioinorganic chemistry $\cdot$ cysteines $\cdot$ NMR spectroscopy $\cdot$ peptides $\cdot$ zinc

[1] C. Andreini, L. Banci, I. Bertini, A. Rosato, J. Proteome Res. 2006, 5, 196.

[2] J. M. Berg, Curr. Op. Struct. Biol. 1993, 3, 11.

[3] H. Takinowaki, Y. Matsuda, T. Yoshida, Y. Kobayashi, T. Ohkubo, Protein Sci. 2006, 15, 487.

[4] J. Penner-Hahn, Curr. Op. Chem. Biol. 2007, 11, 166.

[5] I. Janda, Y. Devedjiev, U. Derewenda, Z. Dauter, J. Bielnicki, D. R. Cooper, P. C. F. Graf, A. Joachimiak, U. Jakob, Z. S. Derewenda, Structure 2004, 12, 1901.

[6] J. F. Collet, J. C. D'Souza, U. Jakob, J. C. A. Bardwell, J. Biol. Chem. 2003, 278, 45325.

[7] L. B. Poole, Arch. Biochem. Biophys. 2005, 433, 240.

[8] Y. G. Shi, J. M. Berg, Chem. Biol. 1995, 2, 83.

[9] A. K. Petros, A. R. Reddi, M. L. Kennedy, A. G. Hyslop, B. R. Gibney, Inorg. Chem. 2006, 45, 9941.

[10] L. Regan, N. D. Clarke, Biochemistry 1990, 29, 10878.

[11] M. Favre, K. Moehle, L. Y. Jiang, B. Pfeiffer, J. A. Robinson, J. Am. Chem. Soc. 1999, 121, 2679.

[12] A. B. P. Lever, Inorganic Electronic Spectroscopy, Elsevier, Amsterdam, 1984.

[13] U. Jakob, M. Eser, J. C. A. Bardwell, J. Biol. Chem. 2000, 275, 38302.

[14] M. Vasak, J. H. R. Kagi, H. A. O. Hill, Biochemistry 1981, 20, 2852.

[15] Jakob et al. measured a binding constant $\mathrm{K}_{\mathrm{ZnHps33}}$ of $10^{17.4}$ for ZnHsp33 at $\mathrm{pH} 7.5$ by competition experiments with TPEN. The binding constant they used for the ZnTPEN complex was the absolute binding constant $\left(\beta_{11}=10^{16}\right)$. The apparent binding constant for ZnTPEN can be calculated by taking into account the protonation constants of TPEN. The actual value is $10^{15.2}$ at $\mathrm{pH}$ 7.5. Thus, $\mathrm{K}_{\mathrm{ZnHps33}}$ is rather $10^{16.6}$ at $\mathrm{pH} 7.5$.

[16] K. Wüthrich, NMR of Proteins and Nucleic Acids, Wiley, New York, 1986.

[17] G. Wagner, W. Braun, T. F. Havel, T. Schaumann, N. Go, K. Wuthrich, J. Mol. Biol. 1987, 196, 611.

[18] A. Brünger, A system for X-ray Crystallography and NMR. X-PLOR, version 3.1, Yale University Press, New Haven, CT, 1992.

[19] H. Szmacinski, W. Wiczk, M. N. Fishman, P. S. Eis, J. R. Lakowicz, M. L. Johnson, Eur. Biophys. J. 1996, 24, 185.

[20] M. Ilbert, J. Horst, S. Ahrens, J. Winter, P. C. F. Graf, H. Lilie, U. Jakob, Nat. Struct. Mol. Biol. 2007, 14, 556. 